\title{
MEGACRYSTS FROM GRIBA KIMBERLITE PIPE (ARKHANGELSK PROVINCE)
}

\author{
By S.I. Kostrovitsky ${ }^{1}$, E.M. Verichev ${ }^{2}$, V.K. Garanin ${ }^{3}$, L.V. Suvorova ${ }^{1}$, I.V. Aschepkov ${ }^{4}$, V. Malkovets ${ }^{4}$, W.L. Griffin ${ }^{5}$ \\ ${ }^{1}$ - Inst. of Geochemistry, Irkutsk, Russia; ${ }^{2}$ - Arkhangelskgeolrazvedka, Arkhangelsk, Russia; ${ }^{3}$ - Moscow State University, \\ Moscow, Russia; ${ }^{4}$ - Inst. of Geol., Geophys. and Mineral., Novosibirsk, Russia; ${ }^{5}$ - CSIRO Div. of Explor. and Mining, \\ Australia
}

The composition of macro/megacryst minerals from Griba kimberlite pipe, Arkhangelsk province, Russia was studied. The mineral association includes garnet, clinopyroxene, picroilmenite (magnesian ilmenite), phlogopite as well as garnet-clinopyroxene intergrowths. The crystalline inclusions, involving mainly clinopyroxene and picroilmenite were studied in garnet megacrysts. Mineral composition was analyzed by microprobe "JEOL" JXA-50A at Moscow State University and JCXA-733 at the Institute of Geochemistry, Irkutsk. The mineral geochemistry was investigated by the proton microprobe in CSIRO Div. of Exploration and Mining, Australia.

\section{MINERAL COMPOSITION}

Picroilmenite is a predominant mineral of the kimberlite heavy fraction. It occurs as rounded, ovalflattened and fragmental-angular grains up to $1 \mathrm{~cm}$ and over and as microcrystalline inclusions in garnet and phlogopite megacrysts. We have studied the composition of both macro/megacryst grains, varying in size from 5 to $15 \mathrm{~mm}$ and picroilmenite microinclusions $300 \times 20$ to $400 \times 250$ microns. In addition to rounded and rounded-oval inclusions some of them are sliced and angular-like with resorption margins. Tables 1 and 2 give the representative picroilmenite composition.

\section{Table 1. Representative compositions of picroilmenite from pipe Griba.}

\begin{tabular}{|l|c|c|c|c|c|c|c|}
\hline & 1 & 2 & 3 & 4 & 5 & 6 & 7 \\
\hline $\mathrm{SiO}_{2}$ & 0,19 & 0,09 & 0,07 & 0,37 & 0,28 & 0,03 & 0,3 \\
\hline $\mathrm{TiO}_{2}$ & 55,33 & 56,06 & 50,59 & 54,51 & 55,18 & 51,46 & 54,53 \\
\hline $\mathrm{Al}_{2} \mathrm{O}_{3}$ & 0,45 & 0,52 & 0,47 & 0,48 & 0,26 & 0,28 & 0,42 \\
\hline $\mathrm{Cr}_{2} \mathrm{O}_{3}$ & 2,19 & 1,64 & 8,31 & 2,04 & 2,62 & 7,78 & 2,4 \\
\hline $\mathrm{Fe}_{2} \mathrm{O}_{3}$ & 6,22 & 3,28 & 7,4 & 7,52 & 4,02 & 4,22 & 3,6 \\
\hline $\mathrm{FeO}$ & 21,55 & 26,42 & 20,12 & 19,77 & 23,45 & 24,67 & 24,94 \\
\hline $\mathrm{MnO}$ & 0,18 & 0,22 & 0,47 & 0,22 & 0,32 & 0,31 & 0,26 \\
\hline $\mathrm{MgO}$ & 13,69 & 12,73 & 12,84 & 15,53 & 13,91 & 11,37 & 12,9 \\
\hline $\mathrm{MgTiO}_{3}$ & 48,5 & 43,7 & 44,8 & 52,8 & 47,8 & 39,7 & 44,8 \\
\hline $\mathrm{FeTiO}_{3}$ & 42,9 & 50,8 & 39,4 & 37,8 & 45,3 & 48,4 & 48,73 \\
\hline
\end{tabular}

1-6 - separate macrocrysts, 7 - average of 66 analysis.
Table 2. Representative compositions of picroilmenite inclusions in the garnet megacrysts, pipe Griba.

\begin{tabular}{|l|c|c|c|c|c|c|c|}
\hline & 1 & 2 & 3 & 4 & 5 & 6 & 7 \\
\hline $\mathrm{SiO}_{2}$ & 0,29 & 0,34 & 0,09 & 0,47 & 0,18 & 0,39 & 0,32 \\
\hline $\mathrm{TiO}_{2}$ & 56,13 & 54,85 & 54,22 & 56,25 & 56,23 & 53,9 & 55,21 \\
\hline $\mathrm{Al}_{2} \mathrm{O}_{3}$ & 1,15 & 0,93 & 0,68 & 0,91 & 0,57 & 0,99 & 0,81 \\
\hline $\mathrm{Cr}_{2} \mathrm{O}_{3}$ & 3,2 & 3,46 & 4,37 & 2,41 & 3,01 & 3,63 & 3,17 \\
\hline $\mathrm{Fe}_{2} \mathrm{O}_{3}$ & 0 & 0 & 1,13 & 0 & 0 & 2,27 & 0,75 \\
\hline $\mathrm{FeO}$ & 27,36 & 28,65 & 27,5 & 27,8 & 27,69 & 25,56 & 27,31 \\
\hline $\mathrm{MnO}$ & 0,19 & 0,15 & 0,28 & 0,22 & 0,25 & 0,28 & 0,26 \\
\hline $\mathrm{MgO}$ & 11,78 & 11,55 & 11,82 & 11,83 & 12 & 12,87 & 12,12 \\
\hline $\mathrm{MgTiO}_{3}$ & 41,3 & 39,8 & 40,57 & 41,4 & 41,8 & 43,9 & 41,8 \\
\hline $\mathrm{FeTiO}_{3}$ & 53,8 & 55,4 & 52,99 & 54,6 & 54,1 & 48,9 & 53 \\
\hline
\end{tabular}

1-6 - separate inclusions, 7 - average of 9 analysis.

Picroilmenite macro/megacrysts from Griba pipe are marked by wide variations of major elements, low iron

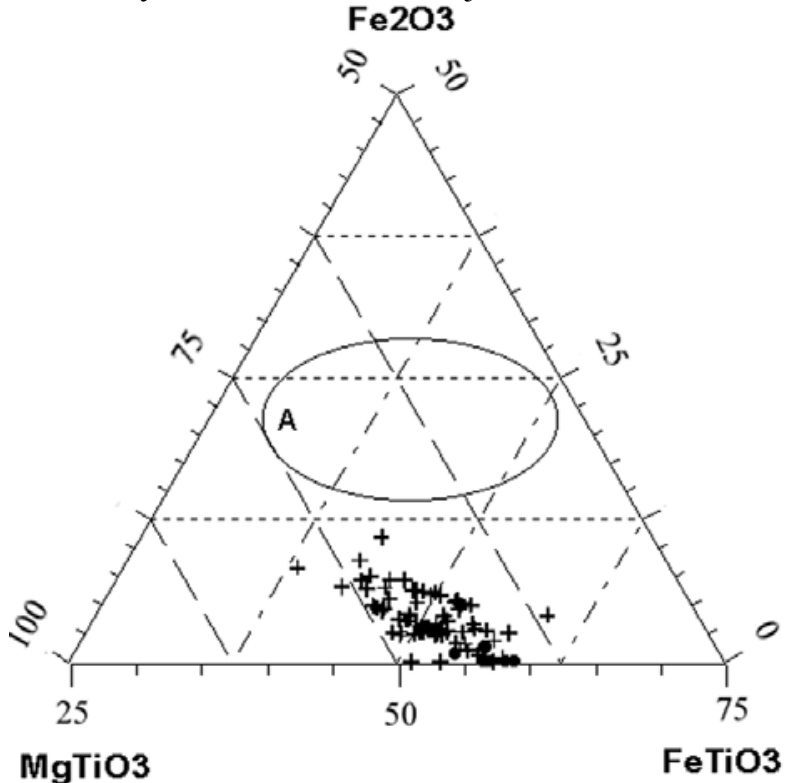

Figure 1. Plot of picroilmenite compositions: plus macro/megacrysts from pipe Griba, black circle - inclusions in garnets from p. Griba, oval $\mathbf{A}$ - field of compositions of picroilmenite from Yakutian province.

oxidation and are rich in chromium (Fig. 1). Average $\mathrm{Cr}_{2} \mathrm{O}_{3}$ and $\mathrm{Fe}_{2} \mathrm{O}_{3}$ contents amount to 2,4 and 3,6 wt \%, 
correspondingly. The macrocryst picroilmenite with such averaged compositional parameters hasn't been found in kimberlites of the Yakutian province. For example, in ilmenites from the Daldyn field the maximum average $\mathrm{Cr} 2 \mathrm{O} 3$ concentrations can reach as high as $1.5-1.8 \%$ (Osennya pipe), while minimum $\mathrm{Fe} 2 \mathrm{O} 3$ content amounts to $10 \%$ (Leningradska pipe). The composition of picroilmenite from inclusions in garnet is similar to that of ilmenite macrocrysts, though the picroilmenite is richer in $\mathrm{Cr} 2 \mathrm{O} 3$ and the poorest in Fe2O3 (Table 2).

Very low concentrations of trace elements from HFSE group $(\mathrm{Zr}, \mathrm{Nb}, \mathrm{Hf}, \mathrm{Ta})$ are also common to picroilmenite from Griba pipe.

Garnet occurs as separate macro/megacrysts. They are typically rounded, in cases with relics of crystallographic shape. Macrocrysts are as a rule not over $1 \mathrm{~cm}$ in size. Intergrowths of garnet and chromediopside are frequently found. Therewith the interractions between minerals are different. Clinopyroxene and garnet of intergrowths commonly occur in equal proportions. These minerals can occur both in the center and on peripheries of megacrysts. In cases clinopyroxene is found on margins of the garnet megacrysts, forming separate grains with uneven borders or discontinuous rim. Megacryst intergrowths with a predominant clinopyroxene and garnet as fine inclusions are rare.

Garnets from Gar-Cpx intergrowths (Table 3) are

\section{Table 3. Representative compositions of garnets from pipe Griba}

\begin{tabular}{|c|c|c|c|c|c|c|c|}
\hline & 1 & 2 & 3 & 4 & 5 & 6 & 7 \\
\hline $\mathrm{SiO}_{2}$ & 41,77 & 41,9 & 41,09 & 40,97 & 41,98 & 41,90 & 42,02 \\
\hline $\mathrm{TiO}_{2}$ & 0,3 & 1,02 & 0,24 & 0,03 & 0,1 & 0,24 & 0,68 \\
\hline $\mathrm{Al}_{2} \mathrm{O}_{3}$ & 21,47 & 19,9 & 19,94 & 21,69 & 19,74 & 21,24 & 20,39 \\
\hline $\mathrm{Cr}_{2} \mathrm{O}_{3}$ & 1,32 & 3,11 & 4,23 & 2,53 & 5,09 & 2,65 & 2,23 \\
\hline $\mathrm{FeO}$ & 10,57 & 9,02 & 7,51 & 7,33 & 7,07 & 8,07 & 9,77 \\
\hline $\mathrm{MnO}$ & 0,29 & 0,34 & 0,4 & 0,38 & 0,33 & 0,36 & 0,35 \\
\hline $\mathrm{MgO}$ & 19,16 & 19,7 & 20,58 & 21,66 & 20,46 & 20,58 & 19,5 \\
\hline $\mathrm{CaO}$ & 4,62 & 4,85 & 4,55 & 4,33 & 4,76 & 4,51 & 4,59 \\
\hline $\mathrm{Na} 2 \mathrm{O}$ & 0 & 0,18 & 0,01 & 0,02 & 0,08 & 0,02 & 0,07 \\
\hline $\mathrm{Total}$ & 99,5 & 100,0 & 98,55 & 98,94 & 99,59 & 99.57 & 99.6 \\
\hline $\mathrm{Pyr}$ & 67,0 & 69,3 & 71,8 & 74,4 & 70,5 & 71,87 & 68,2 \\
\hline $\mathrm{Alm}$ & 20,8 & 17,8 & 14,9 & 14,1 & 14,2 & 15,87 & 19,27 \\
\hline $\mathrm{Spess}$ & 0,58 & 0,68 & 0,80 & 0,74 & 0,67 & 0,73 & 0,71 \\
\hline Gross & 7,2 & 0,87 & 0 & 3,7 & 0 & 3,5 & 3,8 \\
\hline $\mathrm{Ti}-\mathrm{Andr}$ & 0,79 & 2,69 & 0,63 & 0,08 & 0,26 & 0,64 & 1,8 \\
\hline Uvar & 3,7 & 8,7 & 10,9 & 6,9 & 11,9 & 7,22 & 6,0 \\
\hline $\mathrm{Knor}$ & 0 & 0 & 0,96 & 0 & 2,5 & 0,18 & 0,2 \\
\hline $\mathrm{Mg} \#$ & 76,4 & 79,6 & 83,0 & 84,0 & 83,8 & & \\
\hline
\end{tabular}

1-5 - from separate Gar-Cpx intergrowths, 6 - average of 20 analysis for intergrowths, 7 - average of 51 analysis for macro/megacrysts. $\mathrm{Mg} \#=\mathrm{Mg} /(\mathrm{Mg}+\mathrm{Fe})^{*} 100$. similar in composition to the macrocryst garnet, though on the whole they are richer in $\mathrm{Cr} 2 \mathrm{O} 3$ and $\mathrm{MgO}$. By the classification (Dawson, 1980) garnets belong to groups 1, 2 and 9 and are mainly lherzolite-derived. (Fig. 2). It should be noted that titanium and high-titanium pyropes, belonging to groups 1 and 2, correspondingly (the majority of studied grains) are richer in $\mathrm{Cr} 2 \mathrm{O} 3$.

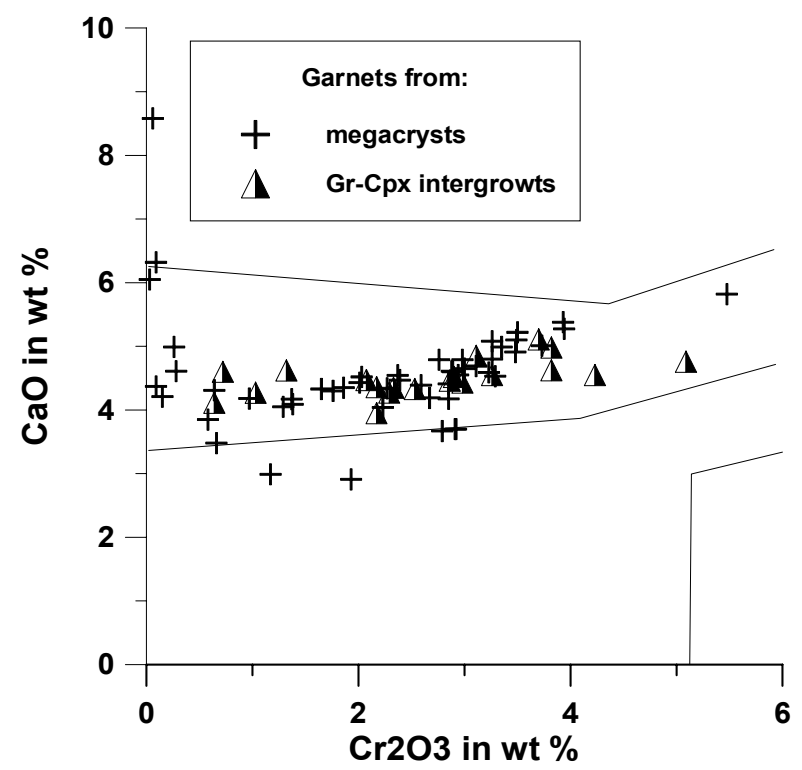

Figure 2. Plot of $\mathrm{Cr}_{2} \mathrm{O}_{3}$ vs $\mathrm{CaO}$ for the garnets from pipe Griba.

Having wide variations in $\mathrm{Cr} 2 \mathrm{O} 3(1.3-9.6 \%)$ and $\mathrm{CaO}$ $(3,6-11.0 \%)$ macro/megacryst garnets are characterized by relatively stable $\mathrm{MgO}(15,4-22,3-$ wt.\%) и $\mathrm{FeO}(5,2-9,9-w t . \%)$ amounts. Variations in garnet composition are mainly due to the decrease of the uvarovite minal content with a corresponding increase of the pyrope one. Garnet and chrome-diopside in intergrowths demonstrate wide variations in composition.

The majority of investigated garnet macrocrysts turned out to be homogenous. Only some macrocrysts show a weak zoning with a slight increase of $\mathrm{Cr} 2 \mathrm{O} 3$ concentration and decrease in $\mathrm{TiO} 2$ content towards peripheries.

Clinopyroxenes occur as separate macro/megacrysts which are rounded, elongated in cases subidiomorphic with crystallographic shape. The macrocrysts are $1 \mathrm{~cm}$ or over in size.

By the classification (Dawson, 1980) pyroxenes from macrocrysts and from intergrowths with garnet from Griba pipe belong to chrome-diopside and juriitic diopside. Pyroxenes (Table 4) are marked by wide variations in content of such oxides as $\mathrm{Cr}_{2} \mathrm{O}_{3}, \mathrm{Al}_{2} \mathrm{O}_{3}$ and $\mathrm{Na}_{2} \mathrm{O} \quad(0.56-2.95 ; \quad 0.86-3.25 ; \quad 1.3-3.0 \quad$ wt. \%, correspondingly) and in $\mathrm{Mg} /(\mathrm{Mg}+\mathrm{Fe})$ and $\mathrm{Ca}(\mathrm{Ca}+\mathrm{Mg})$ ratios, changing within 87.4-94.3; 43,1-50.7 ranges, correspondingly. 
Clinopyroxenes from macrocrysts and from intergrowths have very similar compositions (Fig. 3).

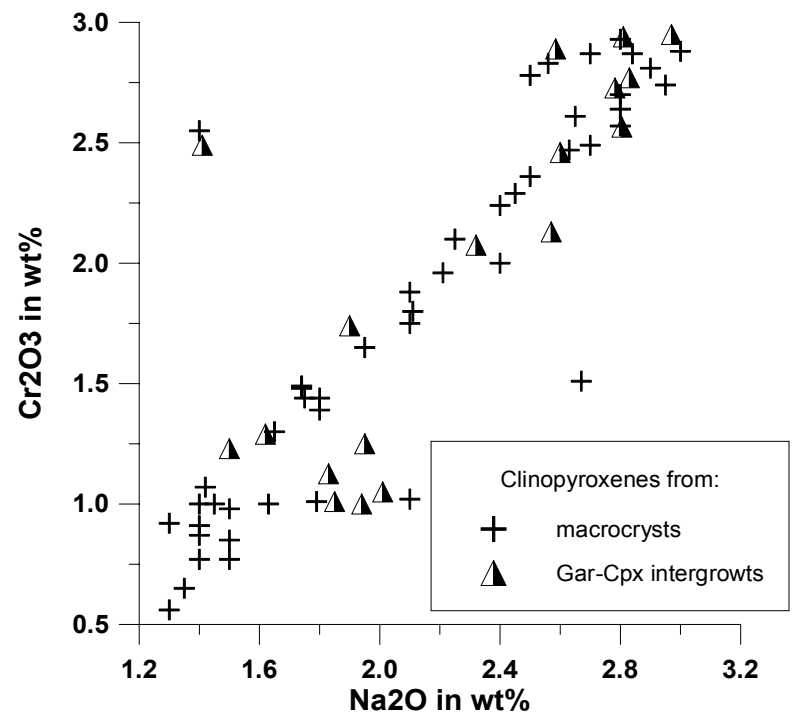

Figure 3. Plot of correlation $\mathrm{Na}_{2} \mathrm{O}$ and $\mathrm{Cr}_{2} \mathrm{O}_{3}$ in clinopyroxenes of pipe Griba.

Rare pyroxene macrocrysts are inhomogeneous in composition. Margins of grains are rich in $\mathrm{Cr}_{2} \mathrm{O}_{3}$ and

\section{Table 4. Representative compositions of clinopyroxene from pipe Griba}

\begin{tabular}{|c|c|c|c|c|c|c|c|}
\hline & 1 & 2 & 3 & 4 & 5 & 6 & 7 \\
\hline $\mathrm{SiO}_{2}$ & 54,45 & 54,41 & 55,41 & 54,57 & 54,83 & 54,67 & 55,21 \\
\hline $\mathrm{TiO}_{2}$ & 0,21 & 0,25 & 0,5 & 0,14 & 0,17 & 0,25 & 0,18 \\
\hline $\mathrm{Al}_{2} \mathrm{O}_{3}$ & 3,47 & 2,87 & 1,88 & 2,64 & 3,04 & 1,78 & 2,48 \\
\hline $\mathrm{Cr}_{2} \mathrm{O}_{3}$ & 1,51 & 0,92 & 0,8 & 2,89 & 2,13 & 1,84 & 1,47 \\
\hline $\mathrm{FeO}$ & 1,97 & 1,8 & 3,47 & 1,445 & 1,44 & 2,81 & 2,04 \\
\hline $\mathrm{MnO}$ & 0,06 & 0,16 & 0,14 & 0,04 & 0,09 & 0,07 & 0,08 \\
\hline $\mathrm{MgO}$ & 14,66 & 15,66 & 16,2 & 15,28 & 15,52 & 16,01 & 15,78 \\
\hline $\mathrm{CaO}$ & 20,75 & 21,35 & 18,76 & 19,46 & 19,1 & 20,16 & 19,91 \\
\hline $\mathrm{Na} \mathrm{O}$ & 2,67 & 1,3 & 2,02 & 2,58 & 2,57 & 2,11 & 2,14 \\
\hline $\mathrm{Total}$ & 99,75 & 98,72 & 99,18 & 99,04 & 98,88 & 100.7 & 99.29 \\
\hline $\mathrm{Mg \#}$ & 92,99 & 93,94 & 89,27 & 94,96 & 95,05 & 91,1 & 93,28 \\
\hline $\mathrm{Ca \#}$ & 50,46 & 49,52 & 45,46 & 47,83 & 46,97 & 47,6 & 47,6 \\
\hline $\mathrm{Cr} \#$ & 22,59 & 17,7 & 22,21 & 42,34 & 31,97 & 40,4 & 27,04 \\
\hline
\end{tabular}

1-5 - separate macrocrysts, 6 - average of 50 macrocryst analysis, 7 average of 19 analysis from Gar-Cpx intergrowths.

$\mathrm{Al}_{2} \mathrm{O}_{3}$ and poor in $\mathrm{MgO}$.

Like picroilmenites, garnets and clinopyroxene from Griba pipe have low concentrations (as compared with megacrysts from the Yakutian pipes) of trace elements from HFSE group ( $\mathrm{Zr}, \mathrm{Nb}, \mathrm{Hf}, \mathrm{Ta})$. REE amount is high and widely varies in particular for clinopyroxene. REE distribution in garnets and clinopyroxene (Fig.4) corresponds to the pattern of their
Mineral / hondrite

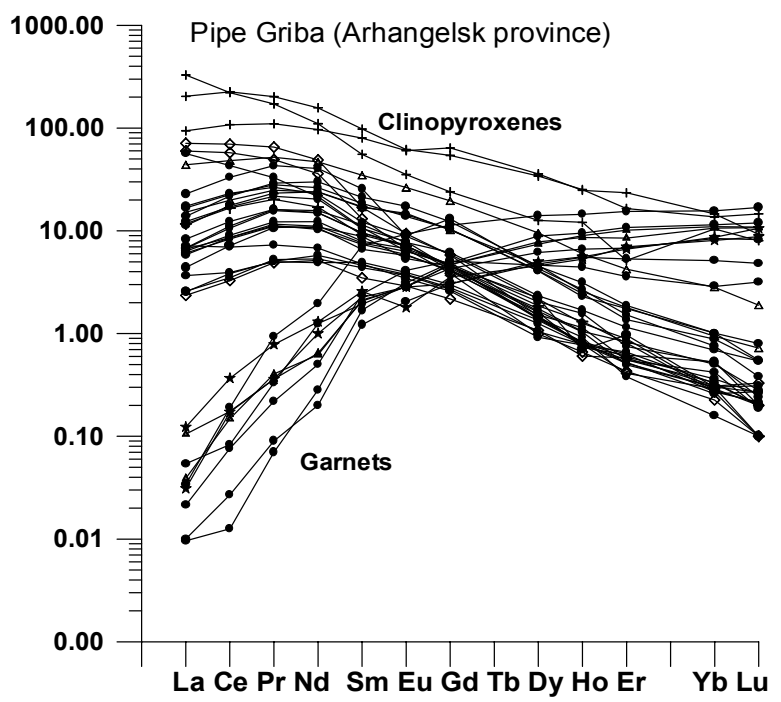

Figure 4. Hondrite normalized rare-earth element patterns for megacrysts of garnet and clinopyroxene from pipe Griba.

Filled circles correspond to different homogeneous megacrysts; plus, triangle, square, romb, star correspond to unhomogeneous megacrysts (2-4 analysis for each grain).

joint crystallization and is typical of minerals from the megacryst association.

Phlogopite is found as large lamellar macro/megacryst crystals with rounded margins (from 2-3 $\mathrm{mm}$ to $15 \mathrm{~mm}$ along a long axis). Phlogopite megacrysts show (Tabl. 5) high magnesium (23-30.2, average as $25.4 \mathrm{wt} / \%$ of $\mathrm{MgO})$ and moderate $\mathrm{TiO} 2(0.32-1.18$, average as 0.67 wt.\%)

Table 5. Some compositions of phlogopite from pipe Griba

\begin{tabular}{|c|c|c|c|c|c|c|c|}
\hline & 1 & 2 & 3 & 4 & 5 & 6 & 7 \\
\hline $\mathrm{SiO}_{2}$ & 42,46 & 42,86 & 41,75 & 39,33 & 40,95 & 40,68 & 41,14 \\
\hline $\mathrm{TiO}_{2}$ & 0,6 & 0,58 & 0,53 & 0,95 & 1,07 & 0,43 & 0,67 \\
\hline $\mathrm{Al}_{2} \mathrm{O}_{3}$ & 11,59 & 12,15 & 11,66 & 10,45 & 11,07 & 11,16 & 11,1 \\
\hline $\mathrm{Cr}_{2} \mathrm{O}_{3}$ & 0,24 & 0,54 & 0,74 & 0,54 & 0,56 & 0,68 & 0,59 \\
\hline $\mathrm{FeO}$ & 3,8 & 3,98 & 3,64 & 3,53 & 3,65 & 3,2 & 3,94 \\
\hline $\mathrm{MnO}$ & 0 & 0 & 0,08 & 0,11 & 0 & 0 & 0,06 \\
\hline $\mathrm{MgO}$ & 25,11 & 25,9 & 25,41 & 23,4 & 24,13 & 24,44 & 25,41 \\
\hline $\mathrm{K} \mathrm{O}$ & 11,51 & 11,92 & 11,37 & 11,07 & 11,26 & 11 & 10,51 \\
\hline $\mathrm{Total}$ & 95,31 & 97,95 & 95,18 & 89,39 & 92,69 & 91,6 & 93,44 \\
\hline $\mathrm{Mg \#}$ & 92,17 & 92,06 & 92,56 & 92,2 & 92,18 & 93,16 & 91.3 \\
\hline
\end{tabular}

1-6 - separate macrocrysts, 7 - average of 39 analysis.

and $\mathrm{Cr} 2 \mathrm{O} 3(0.22-0.85$ average as 0.6 wt. \%) contents, that is typical of the primary phlogopite from mantle peridotite xenoliths. 


\section{DISCUSSION}

Kimberlites from Griba pipe include abundant macrocrysts and megacrysts of picroilmenite, garnet, clinopyroxene and phlogopite. High $\mathrm{MgO}$ and moderate to high $\mathrm{Cr}_{2} \mathrm{O}_{3}$ content is common for minerals. The genetic similarity of minerals and a common paragenesis are confirmed by studies of co-existing minerals from intergrowths and crystalline inclusions. Garnet and clinopyroxene from intergrowths show a clear direct correlation (Fig. 5) in terms of chromium coefficient $(\mathrm{Cr} /(\mathrm{Cr}+\mathrm{Al})$ ratio). Therewith minerals from garnet-clinopyroxene intergrowths and from macrocrysts demonstrate similar variations in composition. It indicates a synchronous crystallization of garnet and chrome-diopside macrocrysts. On the other hand like picroilmenite macrocrysts, crystalline picroilmenite inclusions from garnet megacrysts are characterized by high chromium content. They do not differ from the latter in $\mathrm{MgO}$ concentration. It is the strongest argument to include picroilmenite in the same paragenetic mineral association together with garnet and chrome-diopside. The paragenesis under discussion typically contains chrom-spinelid but not picroimenite as in Griba pipe. Garnet-clinopyroxene intergrowths were crystallized (Krough, 1988) under a wide lowtemperature $\left(732-1125^{\circ} \mathrm{C}\right)$ range. Under temperature decrease the crystallization trend is directed towards the increase of $\mathrm{MgO}$ and $\mathrm{Cr}_{2} \mathrm{O}_{3}$

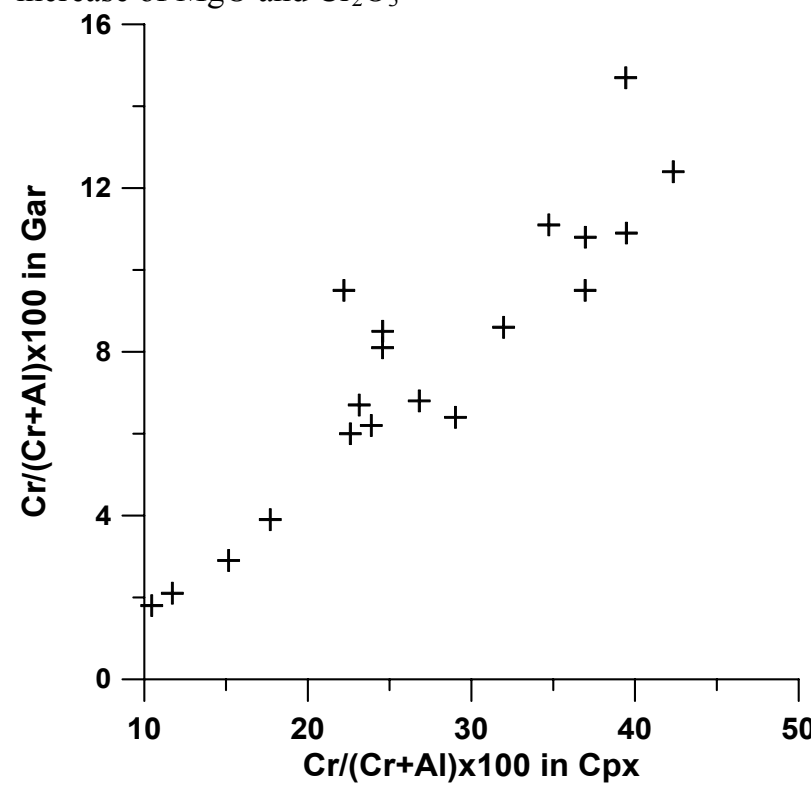

Figure 5. High correlation of compositions of garnet and clinopyroxene from intergrowths from pipe Griba.

contents in clinopyroxenes and decrease of $\mathrm{TiO}_{2}$ abundance in garnets. The crystallization trend of picroilmenite tends towards the $\mathrm{MgO}$ content increase if the crystallization under minimum oxidizing potential is taken as the trend start (Fig. 1). Picroilmenite crystallization (that results from low hematite minal and high $\mathrm{Cr} 2 \mathrm{O} 3$ abundances) approximates to conditions of the diamond crystallization. In this respect kimberlite from Griba pipe is most likely the exception, which demonstrates connection of picroilmenite with diamond.

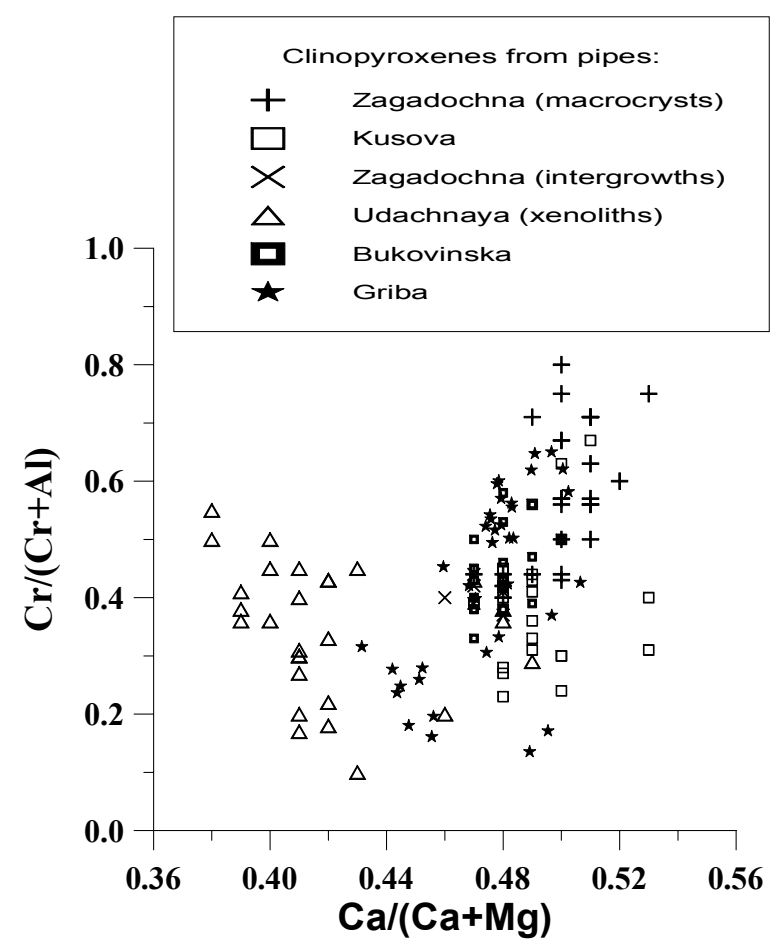

Figure 6. Plot of ratios $\mathrm{Ca} /(\mathrm{Ca}+\mathrm{Mg})$ vs $\mathrm{Cr} /(\mathrm{Cr}+\mathrm{Al})$ for the clinopyroxene from different pipes (see legend). Data for xenoliths are taken from (Sobolev, 1977). Data for the rest pipes are unpublished by authors.

In composition the minerals from the described association differ from the corresponding minerals of the mantle lherzolite-derived xenoliths. However, they show the similarity with the macrocryst mineral association from mica-bearing kimberlites of Zagadochnaya, Kusova and Bukovinskaya pipes (Yakutian province). They were supposed (Kostrovitsky, De Bruin, 1998) to have the phenocryst origin. On a $\mathrm{Ca} /(\mathrm{Ca}+\mathrm{Mg})-\mathrm{Cr} /(\mathrm{Cr}+\mathrm{Al})$ plot chromediopsides from Griba pipe and those from mica-bearing kimberlites form a common trend (Fig. 6). The macro/megacryst mineral association of Griba pipe presumably originates due to the crystallization of the kimberlite melt on protomagmatic stage of the mantle chamber evolution. In addition to ilmenites and other macrocrysts the host kimberlites from Griba pipe are poor in HFSE ( $\mathrm{Zr}$ group) (Krotkov, et al.,2001). The inhomogeneous composition of some megacrysts, wide variations in REE abundance in particular for clinopyroxene suggest an influence of astenosphere 
metasomatic fluid after the cristallization of most minerals.

We suppose that depending on the primary melt composition different paragenetic associations of macro/megacrysts can be crystallized in kimberlites. They include: 1) Fe-Ti (Mir, Udachnaya pipes); 2) high-Mg, Cr (Zagadochnaya, Kusova pipes); 3) high$\mathrm{Mg}, \mathrm{Cr}$, Ti (Griba pipe). Compositions different in terms of major elements are mainly due to inhomogeneous lithosphere source of the melt. Rare element composition of megacrysts in particular for incoherent elements indicates features in the composition of the astenosphere source.

Investigations were supported by RFBR (grant № 0205-64793).

\section{REFERENCES}

Kostrovitsky S.I., De Bruin D. (1998) Ultramafic association of minerals (garnet-ureyit diopsidechromspinelid) in micaceous kimberlites of Yakutian province. In: Extended abstacts, 7IKC, Cape Town, pp. 463-465.

Krogh E.J. (1988) The garnet-clinopyroxene Fe-Mg geothermometer - a reinterpretation of existing experimental data // Contrib. Mineral. Petrol., v. 99 , pp. 44-48.

Aschepkov I.V. (2001): Clinopyroxene barometr for a deep rocks. Abstracts of reports of XIV Russian conference on the experimental mineralogy. Chernogolovka, p. 250.

Dawson J.B. (1980): Kimberlites and their xenoliths. Springer-Verlag Berlin, New York.

Kostrovitsky, Alymova et al. (2003): Structure of the Daldyn field (Yakutian province) on the base of study of picroilmenite composition. This issue. 8IKC.

Krotkov V.V., Kudriavtseva G.P., Bogatikov O.A. et al (2001): New technologies of diamond deposits exploration. Moscow: GEOS, 310p.

Mitchell R.H. (1986): Kimberlites. Mineralogy, geochemistry, and petrology. Plenum Press. New York. $442 \mathrm{p}$.

Sobolev N.V. (1977): Deep-seated inclusions in kimberlites and the problem of the composition of the upper mantle. American Geophys. Union, Washington D.C.

Contact: S.I. Kostrovitsky, PO Box 4019 Irkutsk, Russia, 664033, E-mail: serkost@,igc.irk.ru 